\title{
INITIATION-RESPONSE-EVALUATION (IRE) TECHNIQUE COLLABORATED WITH PANEL DISCUSSION ACTIVITY IN TEACHING SPEAKING SKILL
}

\author{
Dewa Ayu Ari Wiryadi Joni \\ FKIP Universitas Mahasaraswati Denpasar \\ Email: wiryadijoni@ymail.com
}

\begin{abstract}
This study was conducted to present the improvement of the students after the researcher applied IRE collaborated with panel discussion technique in the teachinglearning processes to stimulate the students to speak English actively. The subject of this study was the IV B students of ELSP FTTE Unmas Denpasar in academic year 2016/2017. The subject under study was 29 students. They could improve their speaking skill such as grammar, fluency, pronunciation and comprehension achievement after learning through IRE collaborated with panel discussion technique. The present classroom action study was conducted based on the result of pre-test which was65.17, which showed the students' speaking skill was low. To improve their speaking, the researcher conducted a classroom action research which was conducted in two cycles which in each cycle was consisted of two sessions. There were some research instruments used by the researcher to collect the data, namely: tests, questionnaires and observational sheet. The result of the data analysis of the reflection scores in cycle I, cycle II and cycle III showed the increasing mean figure of 71.9, 75.83 and 81.72. There was a significant increase between the mean figure of cycle I, cycle II and cycle III. These findings showed that IRE technique collaborated with panel discussion activity could improve the students' speaking skill. The result of the analysis of the questionnaire score showed the comparative percentage figures of $67.76 \%, 29.52 \%, 2.72 \%$, $0 \%$ and $0 \%$ for the total responses of questionnaire items options strongly agree, agree, neutral, disagree and strongly disagree respectively. It showed that the subjects' responses toward the technique were positive. This study provided empirical evidences on teaching English speaking skill toward adult learners using IRE technique collaborated with panel discussion activity.
\end{abstract}

Keywords: Speaking Skill, IRE Technique, Panel Discussion

\begin{abstract}
ABSTRAK
Penelitian ini dilakukan untuk menyajikan peningkatan siswa setelah peneliti menerapkan IRE berkolaborasi dengan teknik diskusi panel dalam proses belajar-mengajar untuk merangsang siswa untuk berbicara bahasa Inggris secara aktif. Subjek penelitian ini adalah siswa IV B ELSP FTTE Unmas Denpasar pada tahun akademik 2016/2017. Subjek yang diteliti adalah 29 siswa. Mereka dapat meningkatkan keterampilan berbicara mereka seperti tata bahasa, kelancaran, pengucapan dan pencapaian pemahaman setelah belajar melalui IRE berkolaborasi dengan teknik diskusi panel. Penelitian tindakan kelas ini dilakukan berdasarkan hasil pre-test yaitu 65,17, yang menunjukkan keterampilan berbicara siswa rendah. Untuk meningkatkan kemampuan berbicara mereka, peneliti melakukan penelitian tindakan kelas yang dilakukan dalam dua siklus yang dalam setiap siklus terdiri dari dua sesi. Ada beberapa instrumen penelitian yang digunakan oleh peneliti untuk mengumpulkan data, yaitu: tes, kuesioner dan lembar observasi. Hasil analisis data skor refleksi pada siklus I, siklus II dan siklus III menunjukkan peningkatan rata-rata angka 71,9, 75,83 dan 81,72. Ada peningkatan yang signifikan antara angka rata-rata siklus I, siklus II
\end{abstract}


dan siklus III. Temuan ini menunjukkan bahwa teknik IRE berkolaborasi dengan kegiatan diskusi panel dapat meningkatkan keterampilan berbicara siswa. Hasil analisis skor kuesioner menunjukkan angka persentase komparatif $67,76 \%, 29,52 \%, 2,72 \%, 0 \%$ dan $0 \%$ untuk total tanggapan item pilihan kuesioner sangat setuju, setuju, netral, tidak setuju dan sangat tidak setuju masing-masing. Itu menunjukkan bahwa tanggapan subyek terhadap teknik adalah positif. Penelitian ini memberikan bukti empiris tentang pengajaran keterampilan berbahasa Inggris kepada pelajar dewasa menggunakan teknik IRE yang dikolaborasikan dengan kegiatan diskusi panel.

Kata kunci: Keterampilan Berbicara, Teknik IRE, Diskusi Panel

\section{INTRODUCTION}

Speaking is one of the important skills because speaking and human behavior cannot be separated each other. Speaking is used to express ideas and to communicate to people in civilized world. Speaking seems intuitively the most important skill to master and in an interactive process of constructing meaning that involves producing, receiving and processing information. Speaking is considered a fundamental human behavior that the educators cannot stop researching it. Therefore, speaking is important to analyze and has become a part of the curriculum in language teaching. According to Harmer (1998), speaking activities give opportunities for rehearsal, for both teachers and students to have feedback and motivation. In speaking, students must master the elements of speaking, such as vocabularies, pronunciation, grammar and fluency (Brown, 2000). In learning foreign language especially speaking, many students have less vocabulary mastery and have less grammatical structure mastery.

Based on Harmer (2007), speakers of English must be able to speak in a variety range of different genres and situations and they must be able to speak in a field of conversational strategies. They will need to be able to see in typical functional exchanges as well. But, one point to remember is that each speaker undergoes different speaking processes as they build their own knowledge and have different prior knowledge.

The product of speaking is the communication of thoughts and emotions by the speaker towards the interlocutors. The success of communication is related to how competent a speaker consigns a message. When speakers understand the intention of particular oral language then the meaning of sounds is met. It results from the speaker's production of meaning through blending his prior knowledge with the communicative competence. When these speaking acts have lasted, the comprehension is represented in the knowledge then gathered from the speaking experience and reflect it in society (Dorn and Soffos in Al-Hebaish, 2012). This is due to one of the important components of communicative competence, that is an awareness of the differences between formal and informal language used in real life contexts and situations.

This problem also appears to the IV B students of ELSP FTTE Unmas Denpasar. The students' difficulties occurred when they spoke in English. This was caused by students' limitation in mastering the components of speaking. In 
addition, students practiced speaking English rarely. The students only had chances to practice speaking English when studying in class because most of them speak Indonesian and/or Balinese. In teaching learning process the personal function between teachers and students should be involved. The interaction between teacher and students by communicating well can reach the goal of study. To keep in good communication, both students and teachers must have a good quality in speaking. The teachers have to speak clearly and understandable to their students in order to not only have students get the meaning of what has been said but also they can listen and learn the pronunciation.

In accordance to the above facts, the researcher tries to propose aninnovative technique to improve the students' speaking skill through InitiationResponse- Evaluation (IRE). IRE is mostly used in teaching-learning processes to stimulate students' oral responses to any subjects given in classroom settings. IRE is a technique that can involve all the students to be active. Thus, the researcher is interested in using IRE technique to improve the students' speaking skill.

\section{RESEARCH METHODS}

The subject of this study was the IV B students of ELSP FTTE Unmas Denpasar in the academic year of 2016/2017. The participants were 29 students. Classroom action study was used in this investigation. This classroom action study was concerned with teaching speaking skill through IRE technique. Before giving treatments, the researcher gave pre-test to know the students' preexisting ability. In this class action study, the teaching and learning processes were divided into three cycles which each cycle consisted of two sessions that were done as the following steps:

Cycles I : Planning $\rightarrow$ Action $\rightarrow$ Observation $\rightarrow$ Reflection<smiles>C1CCC1</smiles>

Cycles II : Revised Planning $\rightarrow$ Action 2 $\rightarrow$ Observation $2 \rightarrow$ Reflection 2

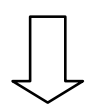

Cycles III : Revised Planning $\rightarrow$ Action 3 $\rightarrow$ Observation $3 \rightarrow$ Reflection 3

In this study the researcher gathered two kinds of data; they were quantitative and qualitative data. To gather quantitative data, the researcher administered pre-test and post-test. Pre-test was conducted to find out the initial problem faced by the students and measure the existing linguistic knowledge in speaking skill. Post-test was conducted to measure whether any change was significantly made after the treatment. The test consisted of three post-tests in the end of each cycle. Post-test was used to examine the effectiveness or the result of the action in cycle I, cycle II and III. The researcher used oral test in the form of impromptu question-answer session. There were five elements of speaking that were used to assess the students' speaking skill, such as pronunciation, vocabulary, grammar, fluency and comprehension adapted from Brown with the scores varied from 50 until 100 points. To gather pretest data, the researcher interviewed the students using English spontaneously; whereas the post-tests were taken from individual speech.

In addition, to gather the qualitative data, the researcher used questionnaires. The use of questionnaires 
in this undertaken study aimed to gather the data of the responses on both the Speaking subject and the IRE technique toward the IV Bstudents of ELSP FTTE Unmas Denpasar which consisted of 10 statements. The response for the statements presented on the questionnaires were formulated by making use of Language Attitude Scale (LAS) in the form of Likert's scale of $1-5$. It stated as follows: 1=strongly disagree; $2=$ disagree; $3=$ neither agree nor disagree; 4=agree; $5=$ strongly agree. This was another research instrument in collecting data through subject's responses. The items consisted of student's opinion about their feeling, speaking skill and IRE technique which was written in Indonesian.

\section{FINDINGS AND DISCUSSIONS}

In this study, the data which were collected could be distinguished into quantitative and qualitative data. The qualitative data were shown by the results of questionnaires which were administered after the cycle III in order to know the effectiveness of IRE. In addition, the quantitative data were taken from the results of the initial reflection and the reflections. Initial reflection (IR) was administered before the cycle I to examine the pre-existing students' speaking skill. The reflection was administered three times, it was after the first, the second and the last cycle; moreover, the data found in reflections were compared to the initial reflection's result so the researcher could see the progress of the students' speaking skill. To make it clear the data were shown in the following graph01 below:

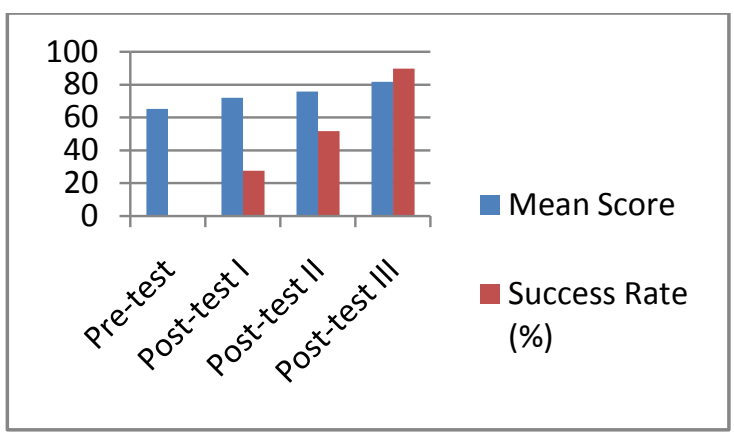

Graph 01. The Mean Scores and Success Rate of Pre-Test, Post-Test 1, Post-Test 2 and Post-Test 3

Based on the graph 01 above, it could be seen that the students' speaking skill was significantly improved. The result of data analysis of the present study showed thatthe use of IRE technique significantly improvedthe speaking skill of the IV B students of ELSP FTTE Unmas Denpasar in academic year 2016/2017.

The data analysis derived from present class action study indicated that the mean of pre-test scores which was obtained by the subjects under study in speaking skill showed the figure 65.71. This mean figure indicated that the ability of the subjects under study in speaking skill was relatively low. The result of data analysis of the reflection score in cycle I showed the increasing mean figure of 71.90. The mean figure of the reflection or post-test I obtained by the subjects under study was much higher than the mean of IR scores. The difference between pre-test and post-test I was 7.93.During teachinglearning processes in cycle I, the students were asked to prepare materials in the form of short speech that would be delivered in the form of panel discussion. The groups were chosen according to their pre-test results; either they would become agree-panelists or disagree panelists. During Initiative phase, they were seen rather anxious when being given tasks to 
hold a group speech in the front. It was understandable because they said that it was their first time to do this kind of activity. They also said that they came quite unprepared because they did not predict what questions would be given to them and/or the questions would need meticulous answers. Thus, their responses during Response phase were not good enough mostly in terms of comprehension. Viewing from pronunciation term, most of them found difficulties in pronouncing unfamiliar words; whereas from the grammar point of view, they mostly used present tense with the misconception of the predicates, especially the use of predicates with or without suffix in the end. In addition, their fluency was mostly affected by their lack of English proficiency and mother tongue. Thus, during Evaluation phase, the researcher focused on their major weaknesses and gave treatments on them.

In cycle II, from the graph 01 above, it was seen that the mean score of post-test II was 75.83 with the success rate was $51.72 \%$. The difference between cycle I and cycle II was 2.93. It was confirmed that there was a slight improvement of students' speaking skill from cycle I to cycle II. Although the improvement was minor, the number of students who could pass the success indicator was significantly increased. For this data, the researcher had revised the planning. In this cycle, before engaging the students into the panel discussion, the researcher gave the students apprehension by giving pictures to trigger their motivation to be ready to have the panel discussion. During Initiation session, the researcher gave a question and clues related to the panel discussion topic of the day and let the students think of what they would say.
Then, in Response session, the students were made into groups as in cycle I and ran the panel discussion activity. Most of the students still looked a bit nervous during the time but their opinions were more comprehensible. They could deliver opinions along with examples and research findings from various resources. Besides, their pronunciation was still influenced by their mother tongue; and they mostly used present tense with quite intelligible vocabulary. In addition, their fluency was quite effortless since they said they felt more confident to talk in the front because they understood what they had said and felt that what they had said was right on point. They also said because the researcher kept smiling and nodding at whatever had been said could automatically motivate them to speak in the front. Hence, during Evaluation session, not only did the researcher evaluate their weaknesses which were mostly in terms of pronunciation, grammar and diction, but she also gave them motivation by praising their efforts on giving their best and telling them that there were rooms for them to develop more.

In cycle III, the graph above showed that the mean score of posttest III was 81.72 with the success rate was $89.66 \%$. The difference between cycle II and cycle III was 6.21 . The improvement detected was considerable. The researcher ran the class the same as previous cycles. She modified the planning by playing a video for them before putting them into groups. In Initiation part, after giving the video, the researcher gave questions related with the topic to check their readiness and immediately arranged them into groups afterward. When Responses part took place, the students were seen more relaxed prepared to be in the front. 
They said they were used to it and knew what to do. They could convey their opinions accompanied by more examples and illustrations supported by research findings and experts. Their pronunciation was enough although they seemed difficult to pronounce unfamiliar words found in research findings and on what experts had said. Their grammar was enough; they were seen concentrated hard on using correct grammar. Their fluency was effortless enough. Accordingly, in Evaluation part, the researcher focused on their pronunciation and grammar. She also gave motivation by commenting on their comprehension which was critical and their fluency which was quite natural.

Moreover, the additional data found from the questionnaires given showed percentage figures derived from option SA, A, N, D and SD are $67.76 \%$, $29.52 \%, 2.72 \%, 0 \%$ and $0 \%$. These result of these figures indicated that $67.76 \%$ subjects strongly agreed, $29.52 \%$ subjects agreed, $2.72 \%$ subjects neither agreed nor disagreed, $0 \%$ subjects disagreed and $0 \%$ subjects strongly disagreed, with the application of IRE technique collaborated with panel discussion activity. It observably indicated the students' responses were seenpositive and that was their attitude and learning motivation heightened significantly.

\section{CONCLUSION AND SUGGESTION}

The main data required for the present study was collected through giving pre-test and post-tests, some supporting data were collected by giving questionnaires in the end of cycle III. Based on the result above, the researcher concluded that using IRE technique collaborated with panel discussion activity could improve students' speaking skill.
The students' learning responseswere positive as well because of the constant application of this technique along with panel discussion activity during instruction processes. Therefore, IRE technique when collaborated with panel discussion activity has given a significant improvement in speaking skillbecause the students could response the questions given and answer it based on their own words and their ideas by exploring more using examples, illustrations supported with research findings and experts.They also could practice speaking skill by having natural communication activities among students and with their teachers.

This IRE technique is a matter of fact considered a traditional way of teaching. However, this technique can be collaborated and/or modified with various learning activities, which makes it more innovative. This would benefit both students and teachers in ways that they could communicate and enjoy the learning atmosphere in classroom settings. The steps of IRE can be done by students and teachers can remain as a facilitator during instruction. Thus, this can be a step forward to have a student-centered learning situation where students can dominate the instructions.This IRE technique when collaborated with panel discussion activity gives a renovated teaching-learning activity which can foster students' critical thinking on conveying ideas and opinions, and trains them to be more cautious when saying something. In addition, the educators could motivate their students by highlighting more on their strengths rather than their weaknesses to give them a sense of achievement to foster their self-confidence to be better in the future. 


\section{REFERENCES}

Al-Hebaish, S., M. (2012). "The Correlation between General SelfConfidence and Academc Achievement in the Oral Presentation Course", Theory and Practice in Language Studies, No. 1, Vol. 2, Page 60-70.

Brown, D. (2000). Principles of Language Learning and Teaching. New York: Longman.

Brown, D. (2000). Teaching by Principles: An Interactive Approach to Language Pedagogy $\left(2^{\text {nd }} E d\right)$. New York: Longman.

Harmer, J. (1986). The Practice of English Language Teaching. London and New York: Longman Group Limited.

Harmer, J. (1998). How to Teach English, An Introduction to The Practice of English Language Teaching. New York: Longman.

Harmer, J. (2007). The Practice of Language Teaching $\left(4^{\text {th }} E d\right)$. New $\mathrm{Y}$ 